\title{
Radial Thermal Conductivity Measurement for SiC Composite Tubes
}

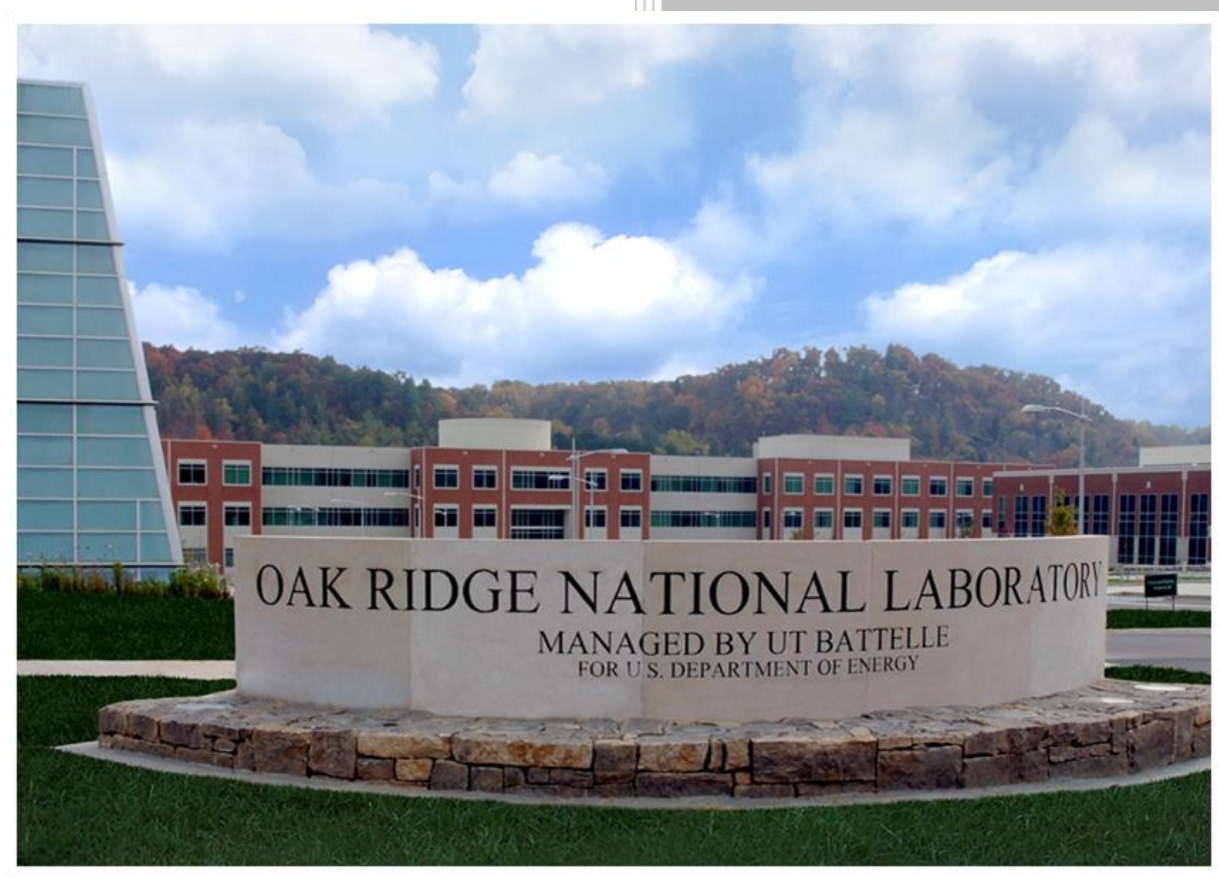

Approved for public release.

Distribution is unlimited.

Takaaki Koyanagi

Yutai Katoh

September 2018 


\title{
DOCUMENT AVAILABILITY
}

Reports produced after January 1, 1996, are generally available free via US Department of Energy (DOE) SciTech Connect.

Website www.osti.gov

Reports produced before January 1, 1996, may be purchased by members of the public from the following source:

\author{
National Technical Information Service \\ 5285 Port Royal Road \\ Springfield, VA 22161 \\ Telephone 703-605-6000 (1-800-553-6847) \\ TDD 703-487-4639 \\ Fax 703-605-6900 \\ E-mail info@ntis.gov \\ Website http://classic.ntis.gov/
}

Reports are available to DOE employees, DOE contractors, Energy Technology Data Exchange representatives, and International Nuclear Information System representatives from the following source:

Office of Scientific and Technical Information

PO Box 62

Oak Ridge, TN 37831

Telephone 865-576-8401

Fax 865-576-5728

E-mail reports@osti.gov

Website http://www.osti.gov/contact.html

This report was prepared as an account of work sponsored by an agency of the United States Government. Neither the United States Government nor any agency thereof, nor any of their employees, makes any warranty, express or implied, or assumes any legal liability or responsibility for the accuracy, completeness, or usefulness of any information, apparatus, product, or process disclosed, or represents that its use would not infringe privately owned rights. Reference herein to any specific commercial product, process, or service by trade name, trademark, manufacturer, or otherwise, does not necessarily constitute or imply its endorsement, recommendation, or favoring by the United States Government or any agency thereof. The views and opinions of authors expressed herein do not necessarily state or reflect those of the United States Government or any agency thereof. 
Westinghouse Electric Company Phase II FOA

NT-18OR02020609

\section{Radial Thermal Conductivity Measurement for SiC Composite Tubes}

Takaaki Koyanagi

Yutai Katoh

Date Published: September 2018

Prepared by

OAK RIDGE NATIONAL LABORATORY

Oak Ridge, TN 37831-6283

managed by

UT-BATTELLE, LLC

for the

US DEPARTMENT OF ENERGY

under contract DE-AC05-00OR22725 



\section{CONTENTS}

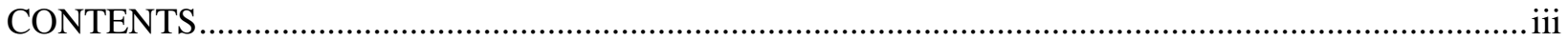

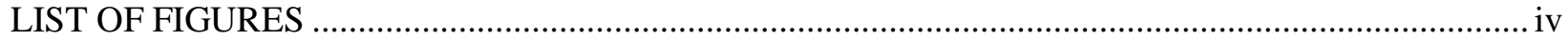

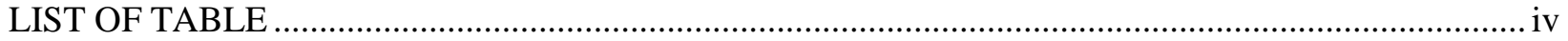

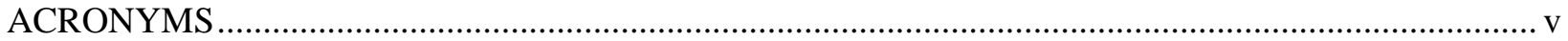

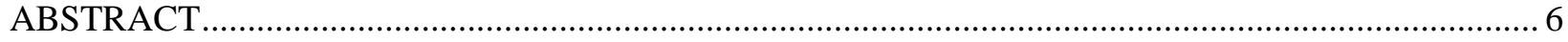

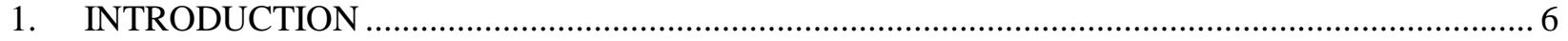

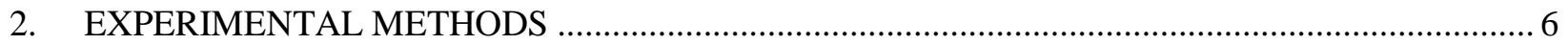

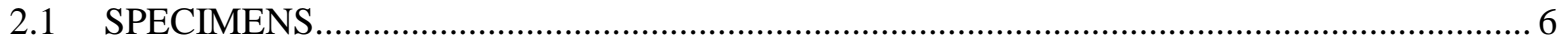

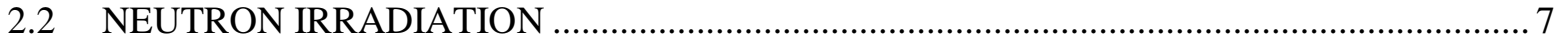

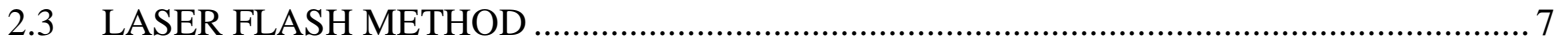

3. THERMAL DIFFUSIVITY OF SiC COMPOSITE TUBES ............................................

3.1 EFFECTS OF SPECIMEN GEOMETRY ON THERMAL DIFFUSIVITY .........................8

3.2 THERMAL DIFFUSIVITY OF NONIRRADIATED AND IRRADIATED SiC

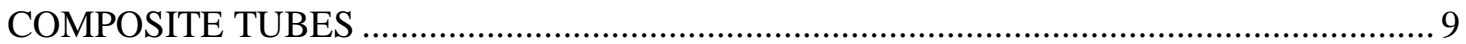

4. THERMAL CONDUCTIVITY OF SiC COMPOSITE TUBES............................................. 10

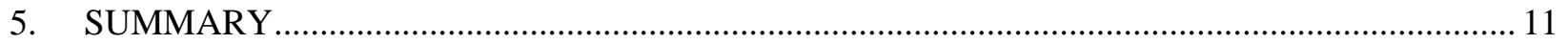

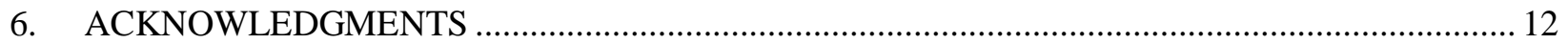

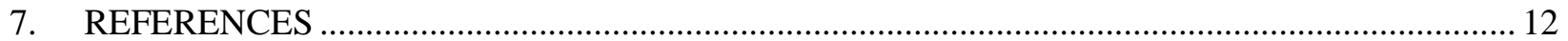




\section{LIST OF FIGURES}

Figure 1. Nonirradiated SiC/SiC composite specimen used for the thermal diffusivity test. ..................... 7

Figure 2. The thermal diffusivity test system, a SiC specimen, and a specimen fixture............................ 8

Figure 3. Time-dependent signal of thermal diffusivity test of nonirradiated curved $\mathrm{SiC} / \mathrm{SiC}$

composite coupon. …........................................................................................................

Figure 4. Temperature-dependent reciprocal thermal diffusivity of nonirradiated and irradiated

$\mathrm{SiC} / \mathrm{SiC}$ composite specimens.

Figure 5. Temperature-dependent thermal conductivity of nonirradiated and irradiated $\mathrm{SiC} / \mathrm{SiC}$ composite tubes.

\section{LIST OF TABLE}

Table 1. Room-temperature thermal diffusivity of glass ceramic specimens with different specimen geometries. 


\section{ACRONYMS}

$\begin{array}{ll}\text { CVI } & \text { chemical vapor infiltration } \\ \text { dpa } & \text { displacements per atom } \\ \text { HFIR } & \text { High Flux Isotope Reactor } \\ \text { LWR } & \text { light water reactor } \\ \mathrm{SiC} & \text { silicon carbide } \\ \mathrm{SiC} / \mathrm{SiC} & \text { SiC fiber-reinforced SiC matrix }\end{array}$




\begin{abstract}
Thermal conductivity is a key property for design and performance assessment of silicon carbide composite $(\mathrm{SiC} / \mathrm{SiC})$ cladding that is being developed for accident-tolerant fuel to be used in light water reactors. The thermal conductivity of $\mathrm{SiC}$ plate has previously been studied, but it was unknown whether it would be different for tubular SiC. The purpose of this report is to provide the thermal conductivity of prototypic $\mathrm{SiC}$ composite tubes under temperatures ranging from $\sim 25^{\circ} \mathrm{C}$ to $\sim 300^{\circ} \mathrm{C}$. Both nonirradiated and neutron-irradiated specimens were evaluated. Thermal diffusivity of curved coupons was measured by a laser flash method. First, the effect of the specimen geometry on thermal diffusivity was investigated using a glass ceramic with known thermal diffusivity. The results showed an insignificant impact of the specimen geometry on the thermal diffusivity in the case of a curvature radius of $\sim 4 \mathrm{~mm}$. Subsequently, nonirradiated and neutron-irradiated $\mathrm{SiC}$ composite coupons with the same geometry as the glass ceramic specimens were evaluated. Thermal conductivity was also obtained using additional data for density and specific heat capacity. Equations were written to express the temperature-dependent thermal conductivities of the nonirradiated and irradiated $\mathrm{SiC}$ composite tubes.
\end{abstract}

\title{
1. INTRODUCTION
}

$\mathrm{SiC} / \mathrm{SiC}$ composite, composed of a silicon carbide $(\mathrm{SiC})$ matrix reinforced with a continuous $\mathrm{SiC}$ fiber, is being developed as cladding for accident-tolerant fuel to be used in light water reactors (LWRs). Westinghouse Electric Company LLC has requested that ORNL measure the through-wall thermal conductivity of small-diameter $\mathrm{SiC} / \mathrm{SiC}$ tubes that were neutron-irradiated under LWR-relevant conditions. Thermal conductivity is one of the most important physical properties for assessing the performance of $\mathrm{SiC} / \mathrm{SiC}$ composite fuel cladding. It is obtained by calculating the product of thermal diffusivity, density, and specific heat capacity. However, there is a significant lack of data for the thermal diffusivity of tube materials because its measurement is challenging owing to the specimen geometry. This is in contrast to plate materials, which have been systematically investigated [1].

Research was undertaken at ORNL to obtain a reliable value for the thermal conductivity of the $\mathrm{SiC} / \mathrm{SiC}$ composite tubes. The thermal diffusivity was determined for curved coupons $(6 \times 6 \mathrm{~mm}$ specimens machined from unirradiated and irradiated $\mathrm{SiC} / \mathrm{SiC}$ composite tubes). A conventional laser flash measurement was applied to obtain the thermal diffusivity. The effects of specimen geometry on the diffusivity were also investigated using glass ceramics specimens with known thermal diffusivity. Thermal conductivities of the tubes were then calculated from the thermal diffusivity, density, and specific heat capacity. The data includes both nonirradiated and neutron-irradiated temperature-dependent thermal conductivity for tubes made of a specific type of nuclear-grade $\mathrm{SiC} / \mathrm{SiC}$ composite. Neutron irradiation occurred under LWR-relevant temperature ranges and dose conditions.

\section{EXPERIMENTAL METHODS}

\subsection{SPECIMENS}

The $\mathrm{SiC} / \mathrm{SiC}$ tubes were fabricated using a chemical vapor infiltration (CVI) process at General Atomics. Hi-Nicalon Type S SiC fiber was used for the reinforcement. The nominal specimen dimensions are $8.5 \mathrm{~mm}$ outer diameter, $7.1 \mathrm{~mm}$ inner diameter, and $16 \mathrm{~mm}$ length. Detailed specimen information can be found in Ref. [2]. The specimens were obtained from two tubes, one nonirradiated and the other neutronirradiated. The tubes were machined into $6 \mathrm{~mm}$ square coupons with an outer curvature radius of $\sim 4.25 \mathrm{~mm}$ by using a Buehler IsoMet 1000 low-speed diamond saw (Figure 1). Three coupons from each tube were tested. 


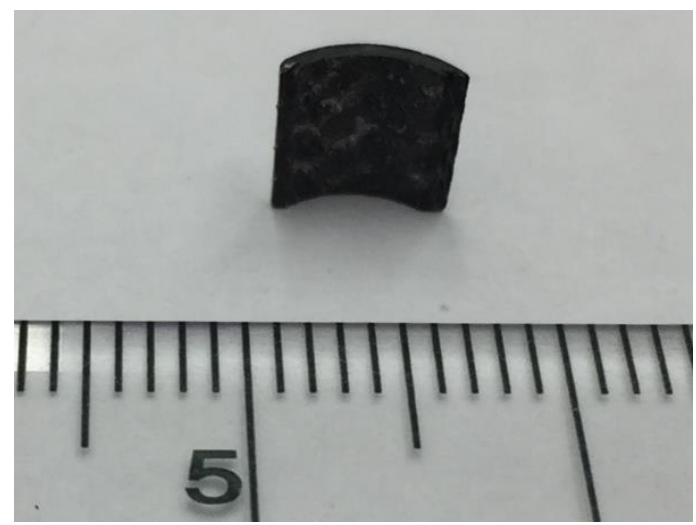

Figure 1. Nonirradiated $\mathrm{SiC} / \mathrm{SiC}$ composite specimen used for the thermal diffusivity test.

The thermal diffusivity of a MACOR machinable glass ceramic was also measured. The MACOR is composed of approximately $55 \%$ fluorophlogopite mica and $45 \%$ borosilicate glass. The thermal diffusivity value reported by the vendor is $0.73 \mathrm{~mm}^{2} / \mathrm{s}$ at $25^{\circ} \mathrm{C}$. Four types of specimens were prepared: (1) $10 \mathrm{~mm}$ square with $1 \mathrm{~mm}$ thickness, (2) $10 \mathrm{~mm}$ square with $1 \mathrm{~mm}$ thickness and $5 \mathrm{~mm}$ outer curvature radius, (3) $6 \mathrm{~mm}$ square with $1 \mathrm{~mm}$ thickness, and (4) $6 \mathrm{~mm}$ square with $0.75 \mathrm{~mm}$ thickness and $5 \mathrm{~mm}$ outer curvature radius. Three specimens were evaluated for each geometry.

\subsection{NEUTRON IRRADIATION}

Fuel cladding in an LWR is irradiated by neutrons and develops a thermal gradient because of the temperature differential between the inner fuel and the surrounding coolant. The sample tube was irradiated in the ORNL High Flux Isotope Reactor to simulate the neutron irradiation expected for a $\mathrm{SiC} / \mathrm{SiC}$ composite cladding in an LWR under normal operations. The tube (sample GA TGI 4) was neutron-irradiated to a total fast neutron fluence of $2.3 \times 10^{25} \mathrm{n} / \mathrm{m}^{2}(\mathrm{E}>0.1 \mathrm{MeV})$ during one reactor cycle, which lasted $\sim 25$ days. The corresponding neutron dose was 2.3 displacements per atom (dpa), assuming $1 \mathrm{dpa}=1 \times 10^{25} \mathrm{n} / \mathrm{m}^{2}(\mathrm{E}>0.1 \mathrm{MeV})[3]$.

The temperature gradient under irradiation results in swelling, which causes a significant buildup of stress [2]. Sample GA TGI 4 was placed inside an irradiation capsule specifically designed to hold a $\mathrm{SiC} / \mathrm{SiC}$ composite tube. The irradiation capsule consisted of a molybdenum heater (dense gammaabsorbing cylinder) at the center, which generated a heat flux of approximately $0.66 \mathrm{MW} / \mathrm{m}^{2}$ at the outer surface of the cladding. The irradiation capsule was designed to accommodate radiation-induced dimensional evolution of the specimen that is surrounded by an engineered aluminum foil. The inner and outer surface irradiation temperatures were $\sim 450^{\circ} \mathrm{C}$ and $\sim 320^{\circ} \mathrm{C}$, respectively. The temperatures were determined by a combination of experimental investigation of the passive $\mathrm{SiC}$ thermometry located inside the tube and by finite-element thermal analysis. Details of the irradiation experiment are given in Ref. [2].

\subsection{LASER FLASH METHOD}

A laser flash method was used to measure the thermal diffusivity of the specimens. The measurements were made in the temperature range of $25^{\circ} \mathrm{C}$ to $\sim 600^{\circ} \mathrm{C}$ in an argon atmosphere. A Netzsch LFA 457 flash diffusivity instrument was used. The sample holders, purchased from Netzsch, are made of aluminum titanate and are covered with a SiC cap (Figure 2). The aluminum titanate holder was coated with graphite. There was no obvious reaction between the specimens and the holders during the testing. The thermal diffusivity was determined from the time required to reach one-half the peak temperature in the 
resulting temperature rise curve on the rear surface. Netzsch software was used to conduct the analysis. A Cowan fitting with finite pulse width correction was used as an analysis method.

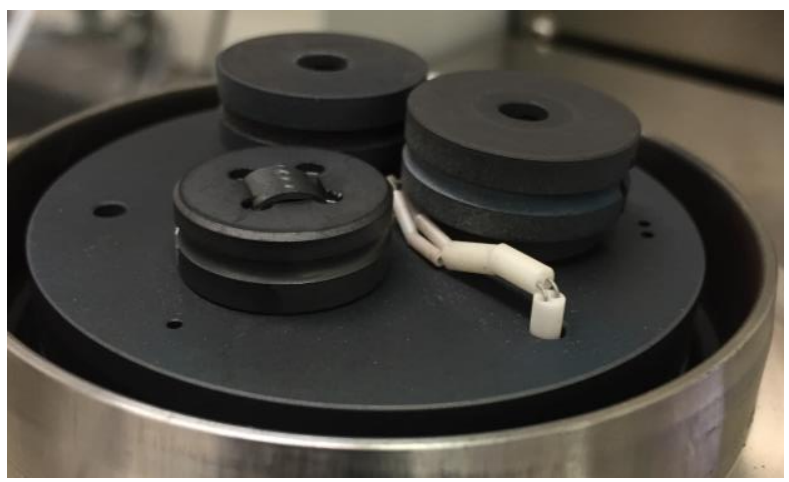

Figure 2. The thermal diffusivity test system, a SiC specimen, and a specimen fixture.

\section{THERMAL DIFFUSIVITY OF SiC COMPOSITE TUBES}

\subsection{EFFECTS OF SPECIMEN GEOMETRY ON THERMAL DIFFUSIVITY}

Room-temperature thermal diffusivities of the glass ceramic specimens with different shapes and sizes are summarized in Table. 1 . The specimens were coated by graphite spray prior to the measurement. One standard deviation of thermal diffusivity was less than $1 \%$. The two flat-plate specimens exhibited thermal diffusivity of $\sim 0.765 \mathrm{~mm}^{2} / \mathrm{s}$, which is within a $5 \%$ difference from the nominal thermal diffusivity of $0.73 \mathrm{~mm}^{2} / \mathrm{s}$ provided by the vendor. Therefore, the system could be used to conduct accurate thermal diffusivity measurement for a small flat plate with dimensions of $6 \times 6 \times 1 \mathrm{~mm}^{3}$. Two types of curved specimens showed very similar thermal diffusivities $\left(\sim 0.8 \mathrm{~mm}^{2} / \mathrm{s}\right)$. Comparing the average thermal diffusivity values for the four glass ceramic specimens, the values for the curved specimens appeared to be slightly larger than those of the flat plates. This trend qualitatively agreed with a previous study, in which laser flash thermal diffusivity measurements were made for $10 \times 10 \mathrm{~mm}$ square $\mathrm{SiC} / \mathrm{SiC}$ composite specimens with different curvatures [4]. However, the difference due to the specimen curvature was only up to $7 \%$ in this study. Therefore, the evaluations of the glass ceramic specimens indicate that the effect of specimen curvature on thermal diffusivity is small for the geometries of the $\mathrm{SiC} / \mathrm{SiC}$ specimen used in this work.

Table 1. Room-temperature thermal diffusivity of glass ceramic specimens with different specimen geometries.

\begin{tabular}{llcc}
\hline $\begin{array}{c}\text { Specimen dimensions }(\mathbf{m m}) \\
(\text { length } \times \text { width } \times \text { thickness })\end{array}$ & \multicolumn{1}{c}{$\begin{array}{c}\text { Curvature radius of } \\
\text { specimen }(\mathbf{m m})\end{array}$} & $\begin{array}{c}\text { Thermal } \\
\text { diffusivity } \\
\left(\mathbf{m m}^{2} / \mathbf{s}\right)\end{array}$ & $\begin{array}{c}\text { One standard } \\
\text { deviation } \\
\left(\mathbf{m m}^{2} / \mathbf{s}\right)\end{array}$ \\
\hline $10 \times 10 \times 1$ & Flat plate, not applicable & 0.765 & 0.006 \\
$10 \times 10 \times 1$ & 5 & 0.801 & 0.006 \\
$6 \times 6 \times 1$ & Flat plate, not applicable & 0.764 & 0.004 \\
$6 \times 6 \times 0.75$ & 4.25 & 0.818 & 0.006 \\
\hline
\end{tabular}




\subsection{THERMAL DIFFUSIVITY OF NONIRRADIATED AND IRRADIATED SiC COMPOSITE TUBES}

Both nonirradiated and irradiated $\mathrm{SiC} / \mathrm{SiC}$ composite specimens had similar dimensions of one of the glass ceramic specimens: $6 \mathrm{~mm}$ square, $0.71 \mathrm{~mm}$ thickness, and an outer curvature radius of $\sim 4.25 \mathrm{~mm}$. A representative time-dependent signal during thermal diffusivity measurement of the nonirradiated specimen is shown in Figure 3 together with a fitting result using a Cowan model with laser pulse width correction. As shown in the figure, the experimental data fitted the model well; this was the case for all the irradiated specimens.

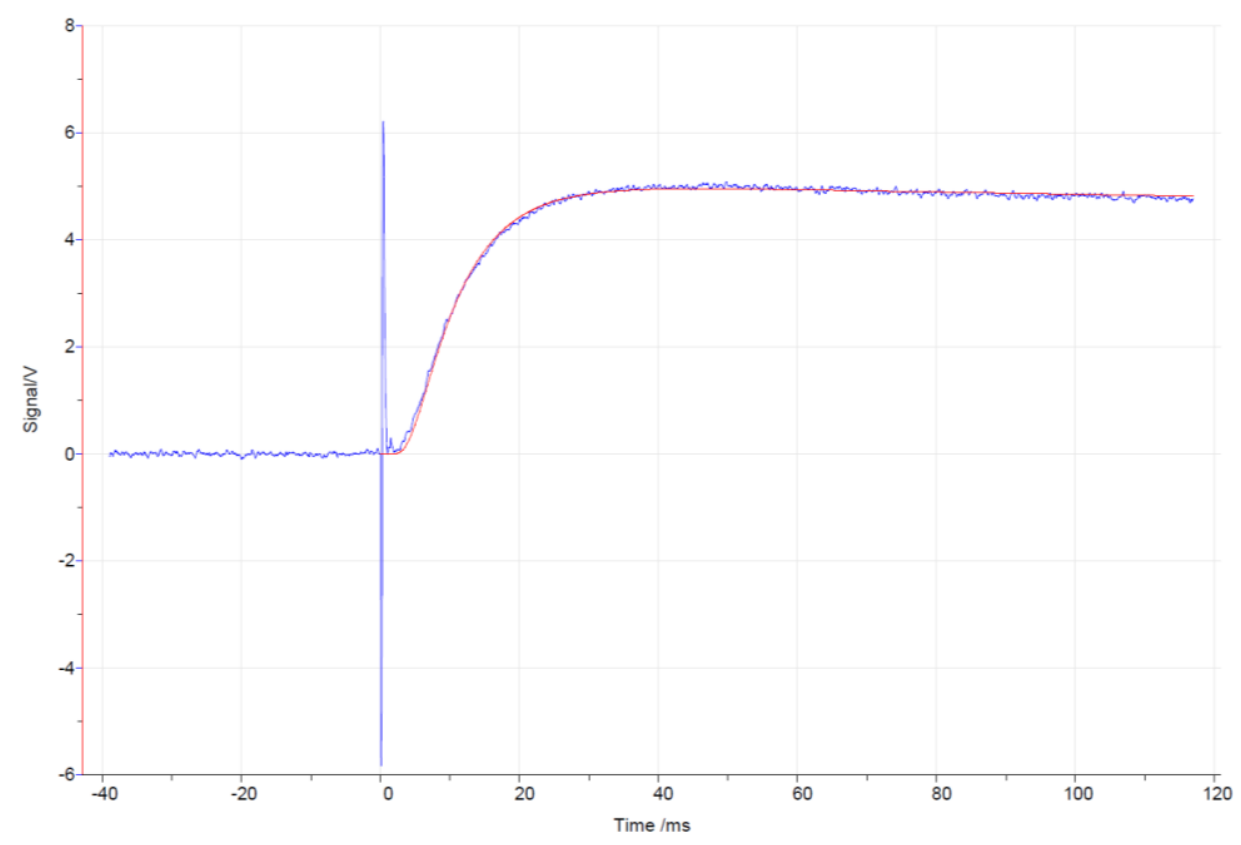

Figure 3. Time-dependent signal of thermal diffusivity test of nonirradiated curved $\mathrm{SiC} / \mathrm{SiC}$ composite coupon. The signal was well fitted with a Cowan model with laser pulse width correction, which is shown with a red line.

Reciprocal thermal diffusivities of both nonirradiated and irradiated $\mathrm{SiC} / \mathrm{SiC}$ composite specimens at different measurement temperatures are plotted in Figure 4. The error bars indicate one standard deviation among measurements of three coupons. An approximately linear relationship was found for nonirradiated specimens up to $600^{\circ} \mathrm{C}$, which is consistent with the behavior of a trans-thickness reciprocal thermal diffusivity of CVI SiC/SiC composite plates [1]. A significant reduction of thermal diffusivity (increment of reciprocal thermal diffusivity) occurred due to neutron irradiation. A linear trend of the temperature dependence appeared up to $\sim 400^{\circ} \mathrm{C}$. It is expected that irradiation defects within the specimens were annealed out during the diffusivity measurements beyond the irradiation temperatures because the irradiation temperature was $\sim 450^{\circ} \mathrm{C}$ at the inner surface and $\sim 320^{\circ} \mathrm{C}$ at the outer surface of the tubes. Annealing of defects causes recovery of thermal diffusivity [5]. Therefore, the irradiated specimen thermal diffusivity data up to $\sim 300^{\circ} \mathrm{C}$ are useful for engineering purposes. With linear fitting of the data, temperature $(T)$ dependent thermal diffusivities of nonirradiated $\left(\alpha_{\text {nonirr }}\right)$ and irradiated $\left(\alpha_{i r r}\right)$ materials in square millimeter per second are empirically expressed by

$$
\begin{gathered}
\frac{1}{\alpha_{\text {nonirr }}}=1.49 \times 10^{-4} \mathrm{~T}+1.27 \times 10^{-1},\left(25-600^{\circ} \mathrm{C}\right) \\
\frac{1}{\alpha_{\text {irr }}}=8.24 \times 10^{-4} \mathrm{~T}+4.25 \times 10^{-1} .\left(25-300^{\circ} \mathrm{C}\right)
\end{gathered}
$$




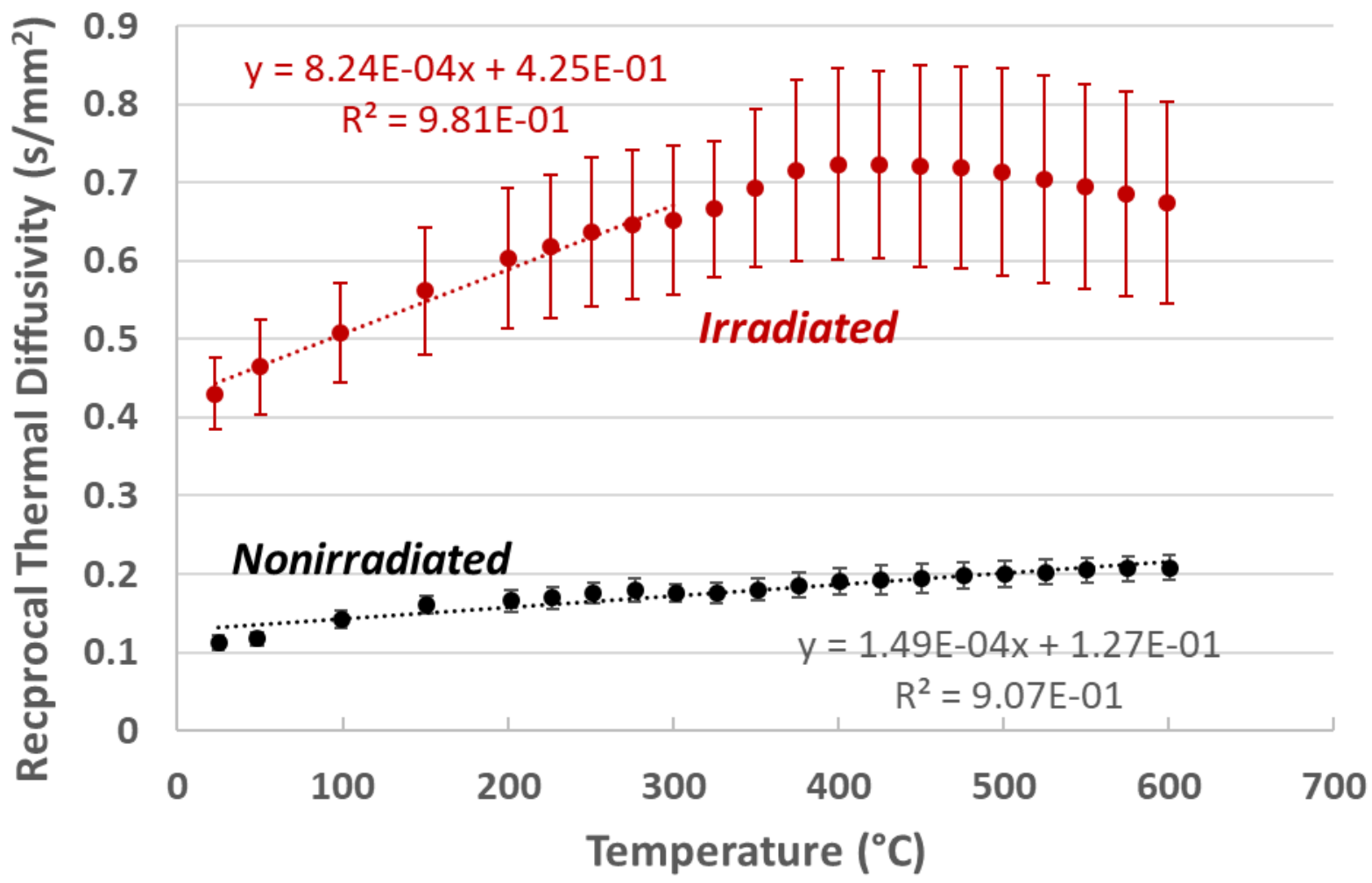

Figure 4. Temperature-dependent reciprocal thermal diffusivity of nonirradiated and irradiated $\mathrm{SiC} / \mathrm{SiC}$ composite specimens.

\section{THERMAL CONDUCTIVITY OF SiC COMPOSITE TUBES}

The thermal conductivity of the tested samples was calculated using the thermal diffusivity $(\alpha)$, bulk density $(\rho)$, and specific heat capacity $\left(C_{p}\right)$. The thermal diffusivities of the unirradiated and irradiated $\mathrm{SiC} / \mathrm{SiC}$ specimens were described, respectively, by Eqs. (1) and (2). The density of the SiC/SiC specimens was $\sim 2.65 \mathrm{~g} / \mathrm{cm}^{3}$ based on dimensional inspection. The specific heat capacity of prototype $\mathrm{SiC} / \mathrm{SiC}$ composite cladding was assumed to be the same as that of a $\mathrm{SiC}$ monolith produced by chemical vapor deposition. This assumption is valid based on the heat capacity measurement conducted by General Atomics. (The data is available in the General Atomics product engineering nuclear materials property manual for $\mathrm{SiC} / \mathrm{SiC}$ Composite Cladding [6]). The specific heat capacity is expressed as follows [7]:

$$
C_{p}(\text { in } J / k g \cdot K)=925.65+0.3772 T-7.9259 \times 10^{-5} T^{2}-3.1946 \times 10^{7} T^{-2},
$$

where $T$ indicates temperature in kelvin and ranges $200-2400 \mathrm{~K}$. It is assumed that the effect of neutron irradiation on the specific heat capacity of the $\mathrm{SiC} / \mathrm{SiC}$ tube was negligible because of the limited change in the density following irradiation. The calculated thermal conductivities of the nonirradiated $\left(k_{\text {nonirr }}\right)$ and irradiated $\left(k_{i r r}\right) \mathrm{SiC} / \mathrm{SiC}$ composite tubes are shown in Figure 5. The temperature-dependent thermal conductivities are based on a polynomial fitting of the data:

$$
\begin{gathered}
k_{\text {nonirr }}=2.11 \times 10^{-10} T^{4}-3.08 \times 10^{-7} T^{3}+1.51 \times 10^{-4} T^{2}-2.93 \times 10^{-2} T+17.2,\left(25-600^{\circ} \mathrm{C}\right)(4) \\
k_{\text {irr }}=-5.25 \times 10^{-9} T^{4}+3.95 \times 10^{-6} T^{3}-1.04 \times 10^{-3} T^{2}+0.108 T+0.697 .\left(25-300^{\circ} \mathrm{C}\right)
\end{gathered}
$$


The unit of $T$ in Eq. (3) and (4) is degrees Celsius. General Atomics reported similar thermal diffusivity values for nonirradiated $\mathrm{SiC} / \mathrm{SiC}$ composite tubes [6]. Thermal diffusivity following neutron irradiation was also similar to the reported values of $\sim 1.5 \mathrm{~W} / \mathrm{m} \mathrm{K}$ at room temperature for a CVI SiC/SiC composite reinforced with Hi Nicalon Type $\mathrm{S}$ fibers that had been neutron-irradiated at $450^{\circ} \mathrm{C}$ to $2.0 \mathrm{dpa}$ [1]. Although the results are not simply compared due to presence of the temperature gradient during irradiation, the results of this work are qualitatively consistent with previous work showing a significant radiation-induced reduction of the thermal diffusivity.

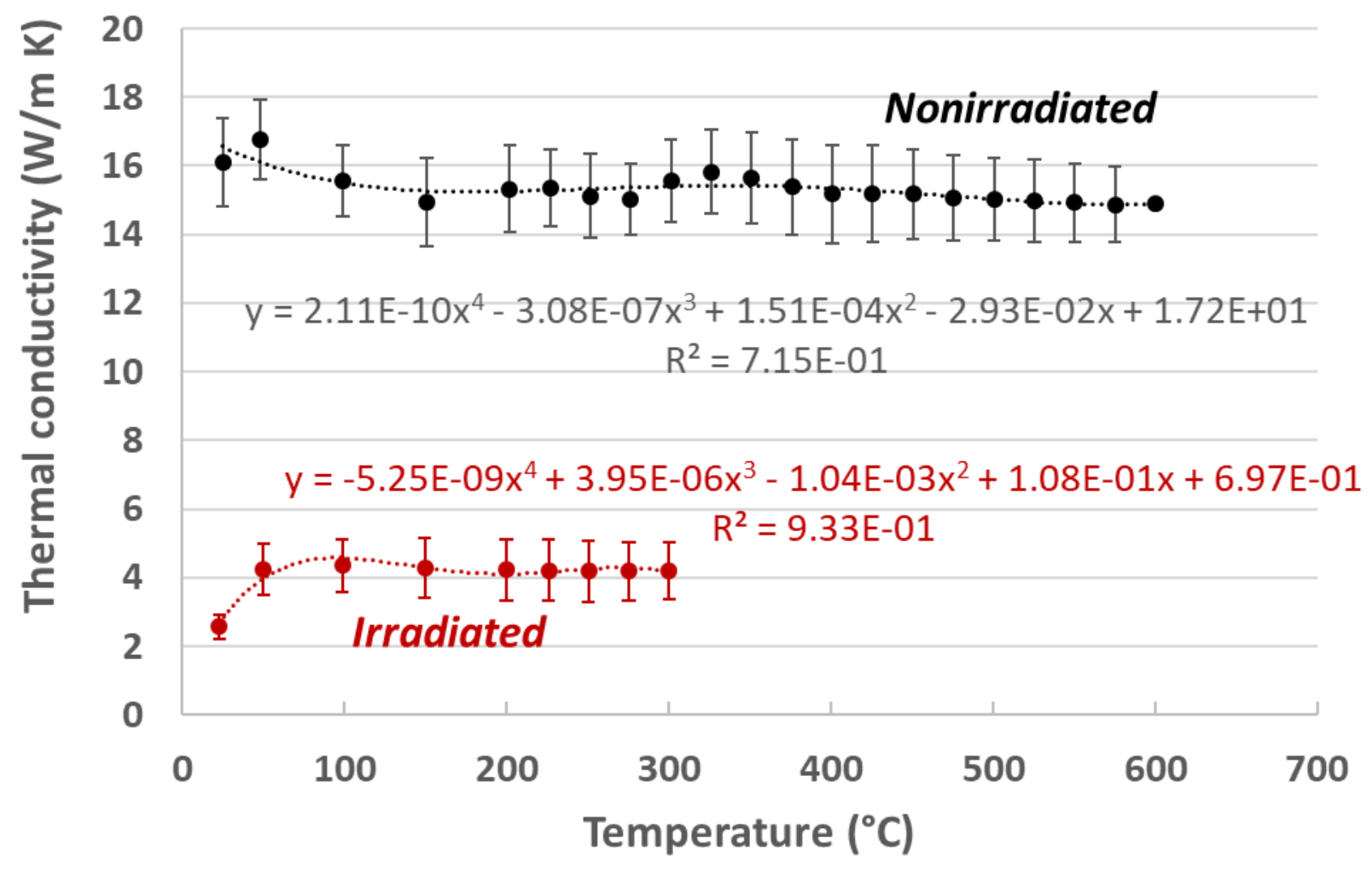

Figure 5. Temperature-dependent thermal conductivity of nonirradiated and irradiated $\mathrm{SiC} / \mathrm{SiC}$ composite tubes. The dotted lines indicate polynomial fitting of the data.

\section{SUMMARY}

This report provides the temperature-dependent thermal conductivities of nonirradiated and neutronirradiated $\mathrm{SiC} / \mathrm{SiC}$ composite tubes, which are expressed by Eqs. (4) and (5), respectively. The material evaluated was the prototypical CVI SiC/SiC composite tubes fabricated by General Atomics. For the irradiated sample, neutron irradiation was conducted under LWR-relevant conditions: irradiation temperature of $\sim 450^{\circ} \mathrm{C}$ and $\sim 320^{\circ} \mathrm{C}$ at the inner and outer surfaces, respectively, and a neutron dose of $2.3 \mathrm{dpa}$. A temperature gradient was created to mimic the in-pile temperature distribution within the cladding. An accurate measurement of thermal diffusivity was a key to obtaining the thermal conductivity of a $\mathrm{SiC} / \mathrm{SiC}$ composite tube because a standard test method does not exist that can determine the thermal conductivity of curved specimens. This work found that a conventional laser flash thermal diffusivity measurement for a flat coupon is applicable to curved specimens machined from $\mathrm{SiC} / \mathrm{SiC}$ composite tubes. 


\section{ACKNOWLEDGMENTS}

The research is sponsored by the US Department of Energy (DOE) Office of Nuclear Energy Nuclear Technology R\&D Program Advanced Fuels Campaign under contract DE-AC05-00OR22725 with UTBattelle, LLC. A portion of this research used resources at the High Flux Isotope Reactor, a DOE Office of Science User Facility operated by Oak Ridge National Laboratory (ORNL). This work also used resources at the Low Activation Materials Development and Analysis Laboratory at ORNL. The aid of Hsin Wang at ORNL in the laser flash experiment is gratefully acknowledged. Christian Deck at General Atomics provided valuable $\mathrm{SiC} / \mathrm{SiC}$ composite tube specimens. Hsin Wang and Peter Mouche provided valuable comments on this report.

\section{REFERENCES}

[1] Y. Katoh, K. Ozawa, C. Shih, T. Nozawa, R.J. Shinavski, A. Hasegawa, L.L. Snead, Continuous $\mathrm{SiC}$ fiber, CVI SiC matrix composites for nuclear applications: Properties and irradiation effects, J. Nucl. Mater. 448 (2014) 448-476. doi:10.1016/j.jnucmat.2013.06.040.

[2] C.M. Petrie, T. Koyanagi, J.L. McDuffee, C.P. Deck, Y. Katoh, K.A. Terrani, Experimental design and analysis for irradiation of $\mathrm{SiC} / \mathrm{SiC}$ composite tubes under a prototypic high heat flux, J. Nucl. Mater. 491 (2017) 94-104. doi:10.1016/j.jnucmat.2017.04.058.

[3] G. Newsome, L.L. Snead, T. Hinoki, Y. Katoh, D. Peters, Evaluation of neutron irradiated silicon carbide and silicon carbide composites, J. Nucl. Mater. 371 (2007) 76-89. doi:10.1016/j.jnucmat.2007.05.007.

[4] J. Zhang, H.E. Khalifa, C. Deck, J. Sheeder, C.A. Back, Thermal Diffusivity Measurement of Curved Samples Using the Flash Method, in: 39th Int. Conf. Adv. Ceram. Compos., 2016: pp. 4356.

[5] A.A. Campbell, W.D. Porter, Y. Katoh, L.L. Snead, Method for analyzing passive silicon carbide thermometry with a continuous dilatometer to determine irradiation temperature, Nucl.

Instruments Methods Phys. Res. Sect. B Beam Interact. with Mater. Atoms. 370 (2016) 49-58. doi:10.1016/j.nimb.2016.01.005.

[6] G. Jacobsen, H. Chiger, Product Engineering Nuclear Materials Property Manual; General Atomics Silicon Carbide Cladding, 2017.

[7] L.L. Snead, T. Nozawa, Y. Katoh, T.S. Byun, S. Kondo, D.A. Petti, Handbook of SiC properties for fuel performance modeling, J. Nucl. Mater. 371 (2007) 329-377.

doi:10.1016/j.jnucmat.2007.05.016. 